口内炎 耳展 $12: 6 ； 451-4551969$

9）部坂正弘 ベーチェト氏病 5 症例のゲルマニン使 用治験 耳展 6:1；118-121，1963
(原稿到着 昭和 47 年 12 月 27 日

別刷請求先 三辺武右衛門

関東聥信病院

⿶ 141 東京都品川区東五反田5丁目9番22号

\title{
アフタ性口内炎の治療
}

热奥望架名

アフタ性口内炎注口腔粘膜に米粒大から小豆 大の, 円形，楕円形，やや不正形の浅い潰崵の できる疾患で，潰崵底汇は線維素様灰白色被苔 があり，潰揚周辺にはせまい紅葷をもつ，発生 原因は不明である。重症な疾患の一分症の時は その疾患名に包括される。このようにアフ夕性 口内炎を定義づけて治療を考元てみよう。

といっても，アフタの治療に筆者は特熱心 でもないし，一家言をもっているわけではな い。数も少く, 疼痛も軽度なアフ夕は, 放置 しても短時日に，自然治療するので，あまり 問題はない，お恥しい次第だが，無定見に，症 状により,ビタミン $\mathrm{B}_{2}, \mathrm{~B}_{6}$ や口内錠を投与し， 口内を清潔任保つように注意しているにすぎな い. 薬効か自然治瘺か，多くはてれで治ってし まう，硝酸銀などの腐蝕は積極的におてなって いない。

問題は, くりかえし再発し，一回の再発時の 治痹期間も長いアフタである，潰愓形も上述の アフタに比し不正で深く, 数も多いし, 疼痛も 強い.このような症例では, Behçet 症候群, カンジダ症, 結核なぞの重要な疾患の一分症で はないか，まづ疑ってみる。しかしいくら検査 しても，はっきりした陽性検査成績の得られぬ ことも多い，最近も次のような症例䎲あい，手 をやいている.
4 年来煩粘膜, 舌飞慢性 再発性アフタがあ り，そのつぞビタミン，抗生物質口内錠の投与 をうけている，潰瘍はやや不正形で，治痖後に 瘕痕を残す。慢性扁桃炎のほか, 赤血球沈降速 度の軽度亢進, 血清 $\gamma$-gl の軽度上昇, 潰湟よ りビリダンス型連球菌の検出，カンジタ抗原抽 出物汇上る皮内反応強陽性のほ加, 特別の所見 はない，血清中カンジダ抗体应証明できず，試 験切除片中にカンジダは証明されなかったが， アァンギソン, マイコスタチン, トリコマイシ ンなごの抗真菌郕の投与で短時日に㵋愓は消失 した。しかし 2〜45月でとに再発をくりか光 している。このような症例をみていると，刺激 をうけやすい部位におてった口内常在菌，たと えばカンジダ，連球菌によるアレルギー反応と 考元られなくもない，口内を清潔保ち，ステ ロイド，抗生物質または非抗生物質性口内錠の 投与のほか，特別の手段をもちあわせない，特 にオラドール，イベルザール，ダントローチな ぞの口内錠の常用は再発防止にぞうだううかと 考えている.

原稿到着 昭和 47 年 12 月 8 日

別冊請求先 奥田 稔

恋 640 和歌山市七番丁

和歌山県立医科大学耳鼻咽喉科

\section{Treatment of Aphtha Stomatitis}

